\title{
Hipervisibilidade e self-disclosure: novas texturas da experiência social nas redes digitais
}

\section{CARLA LUZIA DE ABREU}

\section{Resumo}

A emergência das redes sociais alterou as formas de expressão e de socialização nas sociedades contemporâneas, influenciando as maneiras como nos relacionamos com o outro e com as visualidades. Hoje, as pessoas estão aprendendo a manejar qualitativamente aspectos de sua identidade para serem publicados nas interfaces sociais. Mediadas pelas tecnologias, essas pessoas estão experimentando novos posicionamentos de gênero e sexualidade. As reflexões deste artigo partem dos resultados parciais da investigação de doutorado e examina as práticas

Palavras-chave: Hipervisibilidade, de ver e ser visto nas redes sociais, em particular, se centra em duas questões determinantes para entender essas experiências desde o digital: hipervisibilidade e self-disclosure. 


\section{Hypervisibility and self-disclosure: new textures of social experience in the social networks}

\section{CARLA LUZIA DE ABREU}

\begin{abstract}
The emergence of social networks has changed the forms of expression and socialization in contemporary societies, influencing the ways in which we relate to the other and to the visualities. Today, people are learning to manage qualitatively aspects of their identity to be posted in social interfaces and experimenting new placements of gender and sexuality. The reflections of the article come from the partial results of the doctoral research. The article examines the practices of see and be seen in social networks, in particular, focusing on two vital issues in order to understand the experiences from the digital perspective: hypervisibility and self-disclosure.
\end{abstract}

Keywords:

Hypervisibility, selfdisclosure, social networks 


\section{Hipervisibilidad y self-disclosure: nuevas texturas de la experiencia social en las redes digitales}

\section{CARLA LUZIA DE ABREU}

\section{Resumen}

La emergencia de las redes sociales alteró las formas de expresión y de socialización en las sociedades contemporáneas, influenciando las maneras como nos relacionamos con el otro y con las visualidades. Hoy, las personas están aprendiendo a manejar cualitativamente aspectos de su identidad para publicar en las interfaces sociales. Mediadas por las tecnologías, esas personas están experimentando nuevos posicionamientos. Las reflexiones de este artículo parten de los resultados parciales de la investigación de doctorado y examina las prácticas de ver y

Palabras clave: Hipervisibilidad, autorrevelación, redes sociales ser visto en las redes sociales, en particular, se centra en dos cuestiones determinantes para entender esas experiencias: hipervisibilidad y self-disclosure. 


\section{Introdução}

Nas duas últimas décadas houve uma aceleração gradual e crescente na multiplicação das imagens midiáticas que passaram a desempenhar papel protagonista no cotidiano dos sujeitos, influenciando as formas como percebemos o mundo e a nós mesmos. Concretamente, desde o começo dos anos 9o, foi definida uma guinada à imagem que ficou conhecida como "virada imagética", término cunhado por W. J. T. Mitchell (1994) para descrever a "cultura de imagens", que exigiria dos sujeitos uma análise crítica das formas como construímos conhecimento em torno das imagens, uma reflexão necessária para determinar a função e a influência das visualidades sobre as identidades contemporâneas.

A "cultura das imagens" é uma realidade pela qual não podemos fugir e, intencionalmente ou não, colaboramos diariamente na (re)produção e consumo das visualidades que alimentam a cultura visual. Não por casualidade, o início do século 21 foi palco para a explosão das redes sociais na internet, ambientes no quais as imagens se converteram em veículos de representação, comunicação, socialização e criação de significados, símbolos e imaginários sociais.

Ao introduzirmos as redes sociais em nossas práticas cotidianas colaboramos com a cultura das imagens e com a "hipervisibilidade", ideia trabalhada por Andrew Keen (2012), inspirado nos conceitos de hiper-realidade desenvolvidos por Umberto Eco (2012) e Jean Baudrillard (1978), para definir uma sociedade excessivamente social, no entanto eminentemente individualista e consequentemente solitária. Guiado por estes autores, Keen afirma que "nesse mundo todo transparente, es- 
tamos ao mesmo tempo em toda a parte e em parte alguma, a irrealidade absoluta é a presença real; o totalmente falso é também o totalmente real" (p. 22).

Para o autor, as redes sociais estão se transformando em templos de exibicionismo, onde as identidades estão atreladas demais à própria imagem para perceberem que se tornaram mercadorias da indústria cultural. Keen (2012, p. 87) destaca que as mídias sociais não têm o objetivo de promover a união das sociedades por meio das tecnologias, mas favorecer e permitir que marcas e empresas tenham acesso às pessoas, ou seja, ao invés de sermos usuários das redes sociais, somos, em realidade, seu produto. Somos as informações personalizadas que as redes embalam para vender a seus anunciantes.

Nos dias de hoje, "não estar" nas redes sociais está se convertendo em um comportamento antissocial, mas, paradoxalmente, a experiência de vivermos globalmente conectados parece que não está nos transformando em pessoas mais "sociais". Existem poucas evidências que redes como Facebook, Skype, Instagram ou Twitter estão nos tornando sujeitos mais compassivos ou tolerantes; pelo contrário, é comum o uso desses espaços para práticas desrespeitosas, violentas ou discriminatórias a determinados grupos sociais, mostrando que os discursos que alimentam os preconceitos não são estáticos, mas se atualizam e se reproduzem com a mesma velocidade com que incorporamos as tecnologias em nossas práticas cotidianas.

O conceito de hipervisibilidade também é trabalhado pelo filósofo sul-coreano radicado na Alemanha, Byung-Chul Han (2013), no livro La sociedad de la tranparencia, no qual analisa a questão da exposição excessiva na cultura digital, a perda da intimidade do sujeito conectado e seu empenho em revelar fragmentos de sua vida a uma audiência nunca mensurável. A sociedade da transparência valoriza e reforça a exposição. Cada sujeito "é seu próprio objeto de publicidade. Tudo se mede em seu valor de exposição" (2013, p. 29)․․ O valor é calculado em conectividade, isto é, quanto mais amigos, seguidores e "curtidas" conseguir contabilizar, mais valorizada será a identidade na era da transparência.

Na cultura digital, somos incentivados a expor e consumir intimidades. Essa prática ajudou a diluir as fronteiras entre o público e o privado e a hipervisibilidade é o motor que impulsiona as ciberculturas. Nesse novo tecido social estabelecemos uma relação direta entre "parecer" e "exibir" e a "aparência" domina as situações de intercâmbios desde o digital. Temos que nos expor para existir nas redes sociais e acabamos reduzindo- 
-nos a mercadorias, acompanhando a dinâmica de um mundo que se converteu em "um mercado onde se expõem, se vendem e se consomem intimidades" (BYUNG-CHUL, 2013, p. 68)².

Essa tendência à exposição está sendo chamada por alguns autores de self-disclosure3 (QIAN e SCOTT, 2007; ÍNIGUEZ, BELLI e HARRÉ, 2010). Trata-se de narrar e compartilhar emoções, estados emocionais íntimos e situações do dia a dia com outras pessoas, não necessariamente conhecidas. Nas ciberculturas, a self-disclosure é uma prática comum e podemos encontrar altos níveis de divulgação de informações íntimas ou confidenciais.

\section{Self-disclosure on-line}

Quando entramos em uma rede social parece que um mecanismo invisível nos motiva a expor aspectos íntimos (ou idealizados) de nós mesmos para seguir o fluxo das interações. A self-disclosure se refere à exposição de idiossincrasias particulares a outras pessoas através da tela dos artefatos eletrônicos, especialmente nas relações interpessoais, como são as situações de intercâmbio e socialização nas redes digitais. É uma espécie de comunicação emocional com os demais sujeitos on-line e consigo mesmo (BELLI, 2009), onde são estabelecidas relações discursivas, incorpóreas, baseadas nas negociações que a identidade utiliza para narrar ao "outro", aspectos de sua vida, situação comum nas relações nos ambientes sociais da Web.

No entanto, a self-disclosure é uma via de duas mãos, dependendo de sua elaboração, tanto pode servir para beneficiar a identidade, como para denegri-la. Em outras palavras, tanto pode agregar valor à identidade em situações de hipervisibilidade, como pode apresentar riscos potenciais e colocá-la em situações de vulnerabilidade social, afinal, se criam possibilidades de dar a conhecer intimidades a estranhos ou pessoas mal-intencionadas, fato que pode ter implicações que impactam a vida como um todo.

Apesar de ser uma prática amplamente utilizada pelos sujeitos on-line, a self-disclosure possui níveis diferentes de uso e experiências, nas quais algumas pessoas compartilham mais detalhes sobre suas vidas do que outras. Algumas pessoas cometem exageros, dando a conhecer circunstâncias íntimas, situações embaraçosas ou emoções do mundo interior que não necessariamente precisam ser publicadas. Existe também o risco da identidade tornar-se tão exposta que já não desperte mais a curiosidade no expectador, isso acontece quando suas 
imagens e conteúdos divulgados perdem valor e significado para os intercâmbios on-line.

De qualquer forma, a self-disclosure é um dispositivo eficaz para a construção e a gestão da identidade digital e se tornou parte do jogo para habitar as redes sociais. Consumir, reproduzir, publicar e entreter são os lemas para o êxito do sujeito on-line, situações que nos leva a expor aspectos de nós mesmos e de nossos contextos para o grupo de pessoas que forma parte de nossa rede particular; participantes diretos ou indiretos de nossa atuação no digital. Nesse sentido, podemos dizer que a identidade digital é construída em relação aos contextos desde onde interatua.

As observações realizadas nos processos de minha investigação apontaram que a self-disclosure desempenha um papel importante nos processos de socialização on-line e muitas pessoas aproveitam essa oportunidade para propósitos importantes, como oferecer uma melhor compreensão de si, expor inquietações íntimas, confirmar pontos de vista ou, até mesmo, manipular a percepção dos outros buscando construir uma "imagem" idealizada. A estratégia mais usada é imputar intencionalmente sinais e significados para ressaltar certas características e/ou ocultar outras, ao mesmo tempo em que compartilham histórias e experiências pessoais.

Esse comportamento parece afetar a maioria das identidades nas redes sociais e ajudou-me a entender o sucesso dos espaços para desenvolver as "narrativas ${ }^{4}$ de si". As próprias estruturas dessas interfaces sociais incentivam a criação desses relatos que até pouco tempo atrás só eram possíveis nos contextos locais, reservado a poucas pessoas. Esta tendência colabora para a formação de outros tipos de relações, talvez mais abstratas se compararmos com as formas mediante as quais promovíamos nossas relações pessoais antes das redes digitais, mas igualmente influente nas formas como vamos construindo nossas identidades em relação às outras pessoas.

As identidades digitais encontram na self-disclosure e nas ferramentas tecnológicas, recursos suficientes para sustentar suas performances on-line, isto é, aproveitam as novas texturas da experiência social que esses espaços oferecem para expressar emoções e sentimentos íntimos, por meio de narrativas hipertextuais ${ }^{5}$. Isto pressupõe pensar as redes digitais em termos de significações culturais, práticas sociais de ver e produtora de olhares e percepções. Neste contexto, as imagens, em especial, desempenham um papel ativo e efetivo para o sucesso da visibilidade da identidade digital. 


\section{A popularidade de compartilhar fotos nas redes sociais. Que diz essa prática sobre nossa cultura?}

A necessidade de confirmar a realidade e de realçar a experiência por meio de fotografias é um consumismo estético que hoje todos somos adictos. As sociedades industriais transformaram seus cidadãos em yonquis às imagens; é a forma mais irresistível de contaminação mental. (SONTAG, 2006, p. 43) ${ }^{6}$

Em um tempo onde nem sonhávamos que nossos telefones se tornariam móveis e substituiriam nossas câmaras, Susan Sontag, em 1975, já anunciava nossa predisposição para produzir e consumir imagens. Atualmente, além de produzir e consumir, acrescentamos um elemento a mais neste processo: compartilhar fotos nas redes digitais para serem validadas pelas outras identidades conectadas. Esse comportamento se converteu em algo natural nas ciberculturas e representa um recurso importante para conseguir mais visibilidade e garantir que o perfil na rede social seja atraente e desperte a curiosidade do outro sujeito on-line.

As próprias estruturas das plataformas digitais, em certa medida, promovem esta prática ao exigir que as identidades se apresentem por meio de uma imagem e ao incentivar os intercâmbios visuais, que geram fluxo de dados e audiência ao perfil e à própria rede. Usamos as fotos como conteúdos para nossos perfis e o fazemos com total controle, isto é, podemos deletar as fotos no caso de não gostarmos ou podemos editá-las com grande facilidade.

A popularização das fotografias permitiu a milhões de pessoas fazer um instantâneo em qualquer lugar, sob qualquer pretexto. A indústria cultural, consciente de que vivemos um "mundo-imagem" facilita nossas vidas oferecendo equipamentos acessíveis e aplicativos que permitem manipular a foto, acrescentar filtros e realizar ajustes com a habilidade de um profissional, como divulga a rede mais famosa atualmente para compartilhamento de fotos: "Você aperta o botão, nós fazemos o resto" (slogan da rede Instagram).

Em uma webquest ${ }^{7}$ realizada com alguns participantes do projeto de investigação doutoral, perguntei o que pensavam sobre o comportamento de compartilhar fotos nas redes sociais. Das respostas recebidas, apenas 30\% afirmou ser uma prática desnecessária, a maioria admitiu ser um hábito comum e o fazem com frequência. As respostas apontam que parece existir uma necessidade de nos mostrar e mostrar nos- 
so cotidiano aos demais. Compartilhar fotos nas redes sociais tem a intenção de expressar e expor interesses e afinidades para criar uma "imagem" de quem somos, ainda que seja necessário abrir mão de alguma privacidade. A seguir, algumas das respostas recebidas ${ }^{8}$ :

Me gusta tomar fotos y ponerlas en línea para que otras personas sepan lo que me gusta hacer, sin tener que hacerlo obvio.

Bueno, lo veo como entretenimiento, sirve para bromear con lxs amigxs. Aunque reconozco que en cierto modo también se busca la aprobación de lxs demás, supongo que es una forma de alimentar el ego o suplir algún tipo de carencia, o bien la necesidad de reafirmarse unx mismx, de que le vean como realmente se siente o es, de mostrarlo de algún modo.

En mi opinión es muy interesante porque así podemos cambiar experiencias, conocer nuevos mundos a través de los viajes que hacen nuestros amigos, ver otros objetos, otros físicos, otras caras, nuevas culturas, moda... en fin, hace con que existan muchas maneras de conocer lo desconocido y aventurar en un mundo de imágenes de las cuales sacamos algo de social, pues de una manera o de otra aprendemos. Además juega con nuestros sentidos, gustos y sensaciones, ya que ni siempre estamos de acuerdo con todo lo que vemos o con lo que comparte la gente.

Es como un HEYYYY MIREME AQUI ESTOY!!!!

Mirar por la ventana del vecino siempre ha sido un vicio de muchos desde mucho tiempo, la Internet es nuestra ventana virtual, pero mucho más amplia y con permiso de entrada. Hoy cuanto más compartimos más cabe la necesidad de seguir mirando. ${ }^{9}$

Compartilhar fotos nas redes sociais nos converte em pessoas mais interessantes frente aos olhos de familiares, amigos, amigas, seguidores e seguidoras de nossos perfis. A identidade digital, ao mostrar de forma instantânea o que faz, como faz e com quem faz busca gerar impressões esperadas em seus espectadores, especialmente em términos de alcance de suas relações sociais.

Interessa-nos ser visíveis? Queremos passar inadvertidos ou aproveitar a exposição nas redes sociais? Para habitar esses espaços é determinante decidir que tipo de presença ou que tipo de visibilidade nos interessa. No entanto, o que significa essa obsessão contemporânea de retratar tudo ou qualquer coisa? Por que disparamos nossas câmaras a todo instante "imortalizando" viagens, festas, comidas, momentos, passeios, amigas, amigos ou anônimos? O que faremos no futuro com tantas imagens armazenadas em nossos dispositivos tecnológicos? 
Desenvolvemos um vínculo fetichista com as imagens digitais, tomamos fotos daquilo que não podemos estabelecer uma relação mais permanente e, a imagem, se converte em um signo do vivenciado, embora se torne cada vez mais difícil confirmar a realidade por meio das imagens, uma vez que manipular e editar as fotografias também virou um comportamento comum na cultura visual contemporânea.

Hoje, compartilhar imagens nas redes sociais é uma espécie de febre entre as pessoas que usam esses espaços, daí a crescente moda de tomar, publicar e comentar fotos pessoais. Essa prática, inclusive, colaborou para o surgimento de uma nova expressão escolhida como a palavra do ano de 2013 pelo dicionário Oxford: o selfie, um autorretrato tirado normalmente com um smartphone ou webcam, para ser publicada nas redes sociais. Este tipo de fotografia busca registrar o momento, compartilhar a experiência em tempo real e é comum incluir parte do braço da pessoa segurando a câmera ou o dispositivo móvel, problema este logo resolvido com a aparição do "bastão de selfie", ou "pau de selfie", o gadget mais falado, usado, discutido e ridicularizado do ano de 2014.

Existem selfies de todos os tipos, mas, quem se faz selfies? Muitíssimas pessoas: personalidades, políticos, atletas ou indivíduos absolutamente comuns, independentemente da classe social ou idade, embora ocorra com mais frequência entre os mais jovens. O costume de publicar fotos pessoais nas redes sociais sugere que o mundo que observamos através das telas dos artefatos tecnológicos é mais interessante quando as pessoas se inserem nele e expõe diferentes aspectos e momentos de suas vidas.

O selfie, aparentemente, é mais um reflexo de nossa fascinação pelas imagens e não é uma prática nova; a história da arte nos mostra que registrar a própria imagem é uma ação antiga e forma parte de nossa tradição cultural: de Vincent van Gogh (1853-1890) e Frida Kahlo (1907-1954), a Andy Warhol (1928-1987) e Cindy Sherman (1954-...). A diferença é que hoje existem os dispositivos móveis e a quantidade de autorretratos em circulação cresceu proporcionalmente com a popularidade das redes sociais e sua disseminação nas práticas cotidianas.

Esse comportamento nasce como consequência do desejo de administrar a informação e o conteúdo pessoal, além de distribuí-lo. No entanto, há quem vê nesta prática um perigo potencial ou sintoma de algum distúrbio, como o psiquiatra tailandês Panpimol Wipulakorn, diretor do Departamento de Saúde Mental do Instituto Rajanukul, em Bangkok: "prestar demasiada atenção às fotografias publicadas com a esperança de conseguir 
maior quantidade possível de 'curtidas', é um sintoma de que os selfies estão causando um problema"' ${ }^{\prime \prime}$. Outros estudos, como o publicado no website Best Computer Science Schools ${ }^{\mathrm{I}}$ analisa por meio de uma infografia como esta tendência está transformando os sujeitos em narcisistas, pessoas que não sabem escutar e manifestam uma grande preocupação por si mesmas.

Soraya Mehdizadeh (2010), do Departamento de Psicologia da Universidade de York, Toronto, Canadá, em uma investigação com 100 estudantes universitários, demonstrou que as pessoas com características de personalidade narcisista são as mais ativas e as que mais publicam materiais autopromocionais. Os resultados da pesquisa relacionam o ato de compartilhar fotos pessoais nas redes sociais com egocentrismo, estabelecendo uma articulação entre narcisismo, autoestima e o conteúdo autopromocional.

Estamos nos convertendo em adictos de nós mesmos? Para a psicóloga Pamela Rutledge, diretora do Media Psychology Research Center, em Boston, essa é uma percepção equivocada. Rutledge ${ }^{12}$ explica a mania atual pelos autorretratos como um fenômeno complexo que não pode ser reduzido ao narcisismo. A pesquisadora acrescenta que no ambiente digital, a única maneira de conhecer pessoas é dar a conhecer algo de si mesmo e, a fotografia, é um recurso contemplado no contexto das redes sociais. Publicar fotos é uma estratégia eficiente porque permite nos mostrar como queremos que os outros nos vejam. Rutledge explica que em muitos casos registrar um selfie é mais eficiente para comunicar algo, pois a informação visual traz mais elementos ao contexto; por exemplo, postar um selfie no carnaval é mais eficiente que mandar uma mensagem escrita: "estou no carnaval".

Sem querer demonizar ou absolver o fenômeno de compartilhar fotos pessoais nas redes sociais, como tudo o que se refere às tecnologias, penso que o equilíbrio vai depender do uso que fazemos de seus recursos. Certamente há selfies infelizes, exageros ou imagens com conteúdos questionáveis; mas, isso não significa que o ato de tomar um selfie seja um transtorno psicológico. Possivelmente, pode se tornar um problema se a pessoa depender exclusivamente da aprovação dos outros para se sentir bem consigo mesma. $O$ fato é que a geração de nativos digitais já leva anos fazendo fotos e autorretratos. Este comportamento é considerado algo perfeitamente normal e é uma maneira ativa de participar da cultura digital.

Na minha percepção, os selfies potencializam a autoestima e funcionam como uma espécie de laboratório do "eu", 
além de ajudar a estreitar as relações nas redes sociais, pois são convites para os intercâmbios e interpretações das outras identidades digitais. Em realidade, o sujeito contemporâneo descobriu que pode publicar seus próprios conteúdos e pela primeira vez na história tem o controle editorial sobre si mesmo, podendo criar microespaços de popularidade, gerir sua imagem pública e sua "reputação" nas plataformas digitais. Portanto, os selfies, mais que efeito secundário da cultura digital, podem ser vistos como narrativas visuais, formas de marcar nossa existência no mundo, expressar estados de espírito e compartilhar experiências importantes.

\section{Voyeurismo e exibicionismo digital: ver e ser visto nas redes sociais}

O êxito das interfaces sociais se deve à transformação nas formas como nos comunicamos e socializamos on-line e, também, na maneira como narramos nosso dia a dia. Antes das redes digitais, o conhecimento sobre nossas práticas de subjetividade, intimidades, gostos e preferências eram reduzidas a um número limitado de pessoas, agora, mediadas pelas ferramentas tecnológicas e com a possibilidade de armazenar os fatos cotidianos, escrevemos nossas biografias em tempo real e muitos fazem de seus perfis nas redes sociais verdadeiros realities shows.

Há poucos anos era inimaginável para as pessoas que não nasceram na era do digital a possibilidade de ter como públicas as conversas que tiveram com amigas, amigos ou desconhecidos, além de terem arquivadas grande parte de suas percepções de mundo, repertórios visuais, músicas, sentimentos, sensações, medos, fraquezas, êxitos e fragmentos cotidianos. A vida privada está exposta como nunca esteve nas sociedades e é precisamente essa cultura da exposição, o motor que alimenta a máquina das redes sociais. Transformamo-nos em consumidores da intimidade alheia e temos acesso ao que antes fazia parte do privado nas vidas das pessoas. A própria arquitetura das redes sociais incentiva essa exposição e constantemente somos motivados a teclar, postar fotos, e preencher fichas com dados pessoais.

Este fenômeno característico da nossa época tornou real o ditado popular: "Todos temos dentro de nós algo de voyeur e de exibicionista". Nas redes sociais, as pessoas podem dar liberdade ao instinto de olhar pela fresta para saber mais sobre o outro, conhecer suas preferências, o que faz, aonde vai, com quem vai, se está tenso ou feliz, suas andanças, o que está escutando, 
o último filme que viu, entre muitas outras peculiaridades de sua vida. Por que olhamos o perfil de outras pessoas nas redes sociais? Que espécie de curiosidade provoca esse movimento? Possivelmente, porque a curiosidade seja uma característica inerente aos seres humanos e muitas pessoas não escapam ao impulso de "dar uma olhadinha" na vida alheia.

Uma rede social na internet pode ser pensada como uma imensa praça de alimentação de um shopping center, onde há muitas "câmaras abertas" e as pessoas sabem que estão sendo observadas, ou melhor, sabem que ali existem câmeras, mas se esquecem que seus comportamentos e ações estão expostos à pessoas desconhecidas. O simples ato de abrir a linha do tempo de uma rede social e começar a ler sobre as atividades e pensamentos dos outros é, por definição, um ato voyeurista, afinal, a principal característica do voyeur é não interagir diretamente com o sujeito observado e na maioria das vezes permanece oculto em seu ato de observar.

O mesmo acontece com os conteúdos hipertextuais presentes nos perfis dos e das habitantes das interfaces sociais. Quais são os critérios para escolher aquilo que irá constar em nossos perfis? Somos conscientes quando atuamos de forma voyeurista ou exibicionista? Fiz essa pergunta para alguns sujeitos investigados no projeto de tese doutoral e as respostas me levaram a pensar que atuamos como voyeuristas e exibicionistas de forma simultânea e, em muitos momentos, nem sequer somos conscientes disto, pois parece que construímos certa naturalidade em torno desses comportamentos no contexto das ciberculturas.

No entanto, só se vê aquilo que foi consentido para a exposição, ninguém nos obriga a expor ou tornar público o que não queremos, essas são as condições do jogo e o consentimento está explícito nas normas de ingresso das redes sociais. Preservar-se faz parte do processo de aprendizagem e das experimentações nesses espaços e, pouco a pouco, as identidades vão aprendendo a gerir melhor seus conteúdos, como já observou danah boyd ${ }^{13}$ (2011, p. 57) quando ressaltou a necessidade de vigilância constante sobre os conteúdos postados, pois, o dispositivo que oferece poder nas mídias sociais não é a tecnologia propriamente dita, mas a agência, ou seja, somos os responsáveis por aquilo que publicamos.

Seduzir e ser seduzido é a razão de estar em uma rede social e muitas pessoas se esforçam para desenvolver estratégias de diferenciação como, por exemplo, criar tópicos interessantes, colocar conteúdos engraçados e originais, escolher com 
cuidado as fotos e imagens do perfil, elaborar a imagem que nos representa de forma intencional e criativa e buscar informações úteis para os "amigos" e "amigas" participantes de sua rede. Voyeurismo e exibicionismo são comportamentos comuns nas redes sociais e as pessoas o fazem com a facilidade de quem olha pela janela de casa; são atos que fazem parte da dinâmica destes espaços e servem para oferecer informações e conhecimento sobre o contexto social e cultural das e dos habitantes das redes sociais.

No entanto, não só de imagens e textos vivem as comunidades na internet. Os repositórios de vídeos também são muito utilizados quando o assunto é dar a conhecer fragmentos da vida para uma audiência ampliada. Plataformas como Vimeo e Youtube, fundadas respectivamente em 2004 e 2005, geraram uma situação inédita na internet: armazenar e divulgar vídeos amadores, semiprofissionais, comerciais ou da indústria cultural.

\section{O vídeo como retórica de ação (das identidades não hegemônicas)}

O grande potencial das plataformas de vídeos é criar possibilidades concretas de interações entre as pessoas por meio das "etiquetas" que se relacionam com outros vídeos semelhantes. Por exemplo, uma pessoa interessada no queer ou em temas feministas, acessa o canal de outra que forneceu materiais sobre o assunto e, por meio das ferramentas dessas plataformas, é possível: entrar em contato com o autor ou autora da postagem, enviar uma mensagem sobre o que foi visto, comentar publicamente o vídeo, subscrever-se no canal, recomendá-lo a outras pessoas, entre outras ações.

Essas ferramentas facilitam o trabalho de investigação, pois trazem uma miríade de opções que ajudam nas buscas e seleção dos sujeitos investigados. Na pesquisa de doutorado dediquei atenção especial aos canais cujos conteúdos narrassem experiências cotidianas de pessoas cujas identidades não se encaixam nas classificações identitárias hegemônicas. Também defini como critério de observação, a eleição de canais denominados $v \operatorname{logs}$, ou vídeo-blogs, uma espécie de vídeo-diário nos quais as pessoas expressam ou discutem determinados temas. São narrativas do "eu", o que não significa simplesmente falar de si, mas por em movimento todo um referencial de significados culturais da identidade.

Nesse tipo de vídeos, o que mais atrai é a não pretensão profissional e o aspecto caseiro do material, onde, comumente, 
é a própria pessoa quem grava, edita, publica e divulga o vídeo. Alguns desses $v$ logs são reflexivos, outros se aproximam da comédia, outros simplesmente praticam o exibicionismo, outros denunciam, outros têm tons confessionais, inclusive, há alguns que são elaborados para pedir ajuda para superar determinados momentos ou situações; no entanto, todas estas pessoas têm algo a dizer e compartilhar com outras identidades interessadas em ver e ouvir suas histórias.

Para muitas pessoas, os vlogs são exercícios banais de egocentrismo ou de exibicionismo, no entanto, creio que esse posicionamento é uma ideia superficial sobre este fenômeno em internet, pois essas narrativas digitais do "eu" têm um potencial transformador quando materializam por meio de imagens em movimento, outras práticas de performance que geram visibilidade política, criam conexões com pessoas que pensam de forma semelhante e intercambiam significados entre si.

Os relatos dos vlogs expressam as experiências cotidianas de seus protagonistas e ao compartilhá-las nas plataformas digitais, dúvidas e inquietações do mundo presencial são deslocadas para as ciberculturas. Esses vídeos assumem outros ângulos para expressar subjetividades e, por meio de uma audiência ampliada, a produção de sentidos recebe novos significados a partir das interpretações do que foi visto e dos intercâmbios que são estabelecidos.

Como afirmou Bruner (2003), o sujeito quando narra uma experiência pessoal, reorganiza o que aconteceu e promove uma nova forma de contar o vivido, terminando por reconstruir, também, novos significados para si e para os outros. Quem vê um vídeo-diário se apropria da narrativa do outro e faz suas próprias interpretações do que foi contado, estabelecendo, assim, relações com sua realidade e experiências pessoais. Nesse sentido, o que antes era apenas uma história individual dentro de um determinado contexto, passa a ser a história de muitos e muitas, superando os limites do "eu" e do próprio relato.

Em uma busca simples no Youtube, por exemplo, é possível encontrar centenas de $v \operatorname{logs}$ produzidos por identidades não hegemônicas que relatam suas experiências, impressões ou preocupações por meio das tecnologias. Essa modalidade de vídeo permite a essas identidades contar suas histórias sem intermediários, algo importante a ser considerado, afinal, quando falamos de "representações" é preciso reconhecer que as pessoas com comportamentos não normativos, por exemplo, as identidades de gênero e de sexualidade não heterossexuais, têm, historicamente, poucos espaços de visibilidade e 
em muitas ocasiões são representadas de forma estereotipada ou sensacionalista pelos meios tradicionais de comunicação, com pouca ou nenhuma preocupação com as suas perspectivas ou histórias pessoais.

Durante os processos de investigação da tese de doutorado, trabalhei com alguns e algumas vloggers, como são conhecidas as pessoas que produzem os vídeos-blog, sujeitos que aproveitam de seus talentos narrativos para transformar o vivido em algo público, nos quais "uma mesma pessoa está ocupada, ao mesmo tempo, em viver, em explicar, em reexplicar e em reviver histórias" (CONELLY e CLANDININ, 1995, p. 22). Em geral, os vloggers se comunicam de maneira coloquial, com semelhança a uma comunicação cara a cara, pois a comunicação oral permite esta fluidez de ideias, diferente da narrativa textual que tem outra lógica para a construção das ideias. Alguns exemplos:

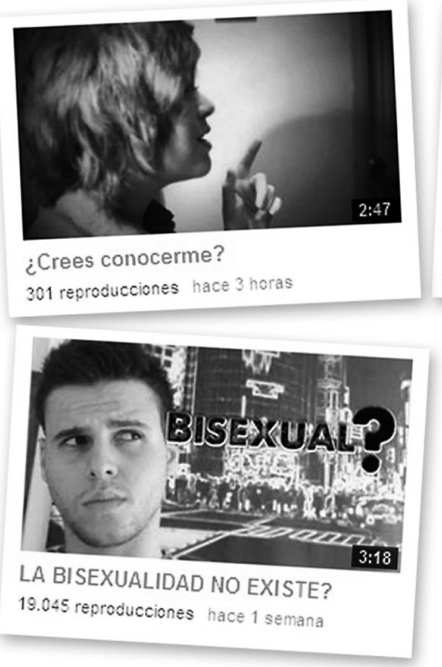

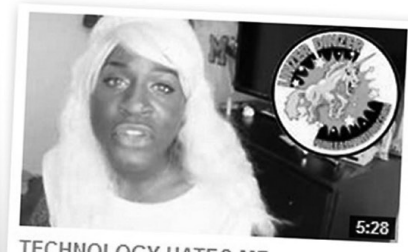

TECHNOLOGY HATES ME

74.880 reproducciones hace 2 meses

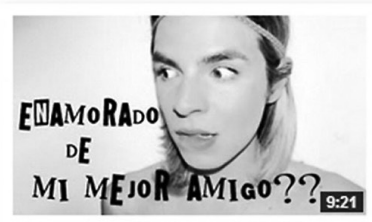

Enamorado de mi mejor amigo . David Allegre / Los Jonas Vloggers 5.418 reproducciones hace 1 mes

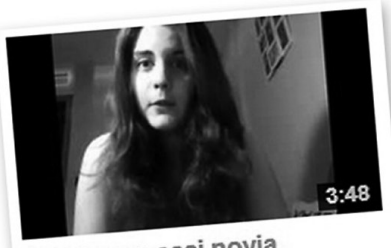

Mi primera casi novia 393 reproducciones hace 2 meses

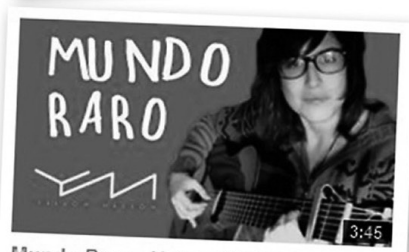

Mundo Raro - Yellow Mellow 238.715 reproducciones hace 1 año
A jovem vlogger do vídeo intitulado "minha primeira quase namorada [mi primera casi novia]" é um exemplo interessante. Ela sempre esteve disponível para ajudar na investigação e trocamos várias mensagens privadas. A jovem reconhece que faz vídeos por "diversão particular" e disse estar surpresa com os quase dois mil assinantes em seu canal, porque, para ela, seu trabalho é "fazer o papel de tonto na frente da câmera, falando coisas bobas”. Em sua opinião, produzir vídeos é uma terapia para conseguir expressar-se, organizar e expor seus pensamentos desde outras formas.
Figura 1

Exemplos de vloggers em Youtube 
Em realidade, mais que "falar coisas bobas", o que a jovem faz é usar as ferramentas tecnológicas para conhecer mais de si mesma. Explora suas reflexões diante da câmara para pensar suas experiências de vida. Em um de seus vídeos, ela disse estar a "meio armário" (em respeito à sua sexualidade) e perguntei se ela não tinha receio de expor-se em uma plataforma de alcance global, já que não estava "totalmente" fora do armário, esta foi sua resposta:

No te voy a engañar, claro que a veces me invade el miedo, y más de una vez he pensado en borrar mi cuenta de youtube, pero siempre deshecho la idea por una simple razón: me gusta lo que hago, y eso está por encima de todo lo demás. Escribir es mi pasión, los vídeos de youtube un suplemento que me hace reír mucho, por lo tanto continuaré haciendo ambas cosas hasta que dejen de gustarme. ${ }^{14}$

A jovem é consciente de suas ações e sabe que seus vídeos podem tirá-la "totalmente" do armário, mas isso não a faz retroceder, prefere correr o risco. A principal característica dos vlogs é a reflexão sobre suas preocupações e experiências cotidianas, muitas delas relacionadas com a identidade de gênero e a sexualidade. No caso dessa moça, minha interpretação é que estamos diante de uma identidade que está prestes a desenvolver-se em uma nova direção e sua produção de vídeos-relatos é uma forma de refletir sobre essas mudanças e como a afetam.

As pessoas que produzem os $v \log$, como nas outras redes sociais, também constroem suas identidades por meio de suas experiências. No caso dos vídeos, é interessante observar como a identidade vai, pouco a pouco, adquirindo intimidade com a câmara à medida que vai produzindo os vídeos. Essas pessoas tornam-se cúmplices de sua própria imagem e vão aprendendo através de seu "espelho-imagem" a melhorar gestualidades ou práticas orais/corporais, assim, é comum ver o protagonista ajustando o cabelo, roupas ou estudando seu sorriso enquanto fala, valorizando de forma continua sua performance diante da câmera. Outro exemplo:

- Hola chicos, ¿cómo están? Lo tema que voy hablar hoy es cómo salir del closet. Me han pedido este vídeo y siento que es bueno compartir este tipo de cosas, porque pues... muchos siguen en el closet, no saben cómo salir del closet, decir a sus papás, a la familia... entonces voy contar mi historia (...) pues llegas un punto de su vida que ya no quieres estar fingiendo lo que no 

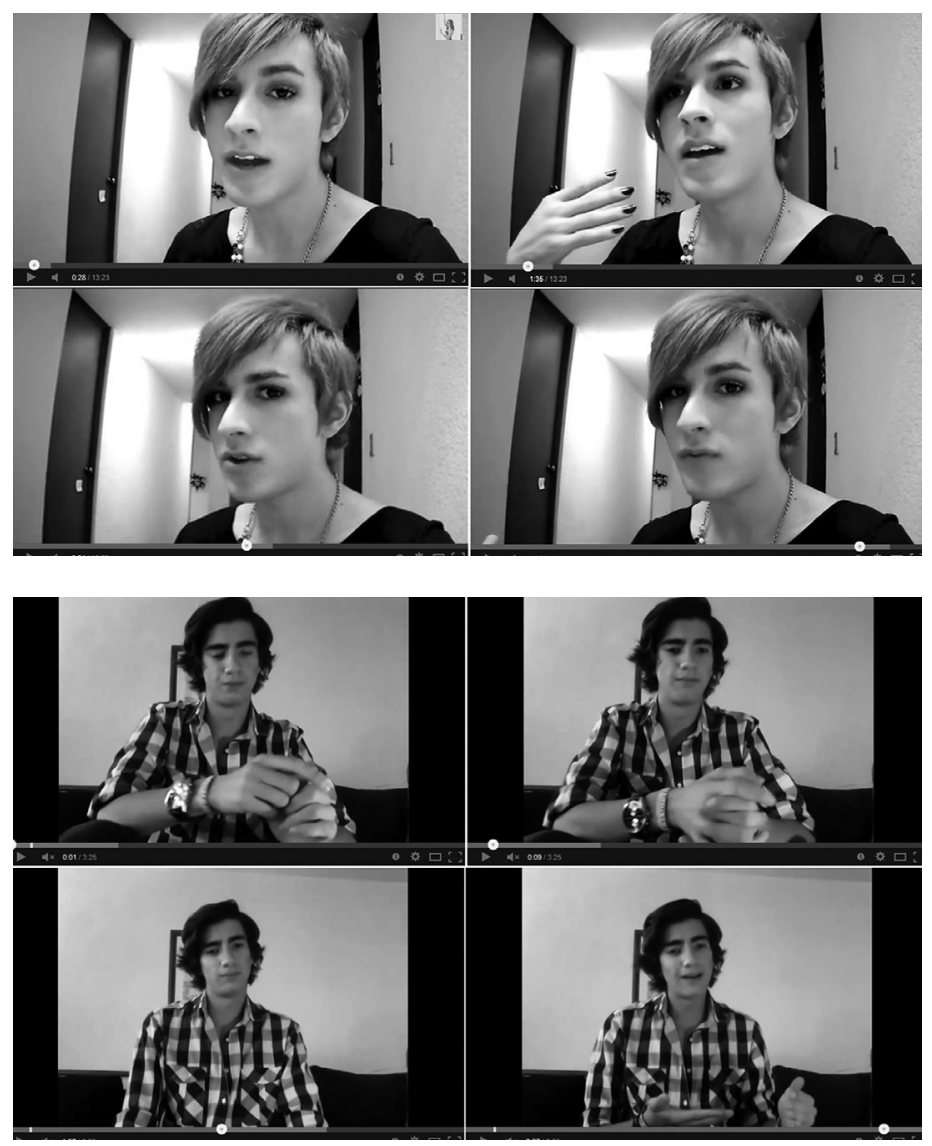

eres. Mí historia no fue tan difícil como otros casos, porque yo siempre fue muy femenino y la verdad la mayoría de las personas ya sabían que era gay ... entonces fue como tipo confirmar. ${ }^{15}$

A jovem estrela do vídeo é um rapaz aparentemente muito cuidadoso com sua imagem e tem plena consciência de que está falando a um público potencial. Sua performance atrás da câmera é acompanhada por olhares sedutores e seu monólogo está salpicado de expressões familiares à multidão LGBT$\mathrm{sIQ}^{16}$. O título do vídeo é "Como saí do armário [Como salí del closet]" e sua credibilidade (até o fechamento deste artigo, o vídeo contava com 368.657 visualizações) está na habilidade do vlogger em contar fragmentos de sua história com a propriedade de que quem viveu a experiência.

O próximo exemplo é de outro rapaz que apesar de se esforçar para emitir naturalidade, se nota que está um pouco tenso:
Figura 2

Capturas de tela do vídeo "Como salí del closet"

Figura 3

Capturas de tela do vídeo "Mi salida del closet" 
Les quiero contar como fue mi salida del closet. Mi salida fue en 31 de diciembre, pero lo hice porque mi mamá cachó unos mensajes justo antes de la cena de año nuevo. Tuve que explicarlo porqué de los mensajes... le cuento de mi orientación sexual y para ella es como un "boom" porque primero ella dijo que no diga a nadie, por favor. Entonces... ¿a quién le digo, con quien me desahogo? ${ }^{17}$

Ele, aparentemente, está na sala de sua casa, sentado no sofá. Suas mãos cruzadas demonstram um grau de nervosismo. Sua voz, maneira de sentar-se e os movimentos de seu corpo não dizem muito de sua orientação de gênero e vamos nos inteirando de sua sexualidade à medida que narra sua história. A reprodução dessa revelação não apenas marca uma retórica de enfrentamento e de self-disclosure, mas também dá a conhecer a identidade do sujeito, na qual o espectador é convidado a participar, cara a cara, de sua história, como se fossem velhos amigos:

Después de un tiempo mí mamá me cuenta que la verdad para ella fue muy fuerte en aquel momento. (...) Ahorita con mi familia va perfecto. Quiero pues que tienen en cuenta, piensa un poquito en sus papás... obviamente que les digan que tiene una orientación sexual diferente es un rollo muy fuerte, entonces les sale como tiempo para pasar su duelo, informarse y todo, pero, pues, si ustedes si sienten preparados para decirlos díganles. ${ }^{18}$

Apesar da natureza íntima e confessional das declarações dos vídeos "saindo do armário", essas produções não são histórias sem estruturas, são reflexões verbalizadas e expõem subjetividades que afirmam "verdades" acerca de um mesmo, geralmente usando uma linguagem informal e próxima. Esses relatos expressam visões de mundo particulares e muitas vezes encontram vários níveis de aceitação e de rejeição, como esses comentários no mural do vídeo anteriormente citado:

Guau! que valiente que eres, a mi aun me da cosas salir, siento que todo mi mundo va a cambiar drásticamente si lo hago, tienes tips?, tienes un nuevo suscribir!!!

Pobre tu viejo loco! no entiendo porque son gais!!!

Felicitaciones, eres muy valiente. Yo intente decirle a mi madre que soy bisexual y cada vez que toco el tema toda mi 
familia habla de lo horrible que es que jamás me aceptarían si lo fuera .. u.u es muy triste que no a todos nos acepten , a algunos solo nos toca quedarnos callados.. :/

Yo lo que no entiendo es porque hablan tanto de la "sociedad" “aceptación" etc etc, no entiendo porque ponen voz de mujercita y porque se visten de rosado. no puede acaso haber un homosexual que no tenga esa voz y se vista así?

Hola, te felicito por haber tenido la valentía de hacerlo, conozco muchos "heteros" lamentando tener que vivir atado una esposa toda su vida.

Yo también soy guapo y no tengo necesidad de convertirme en marica... soy bien hombre...y estoy contento de serlo y amo a las mujeres más que a cualquier cosa en la vida. Eso de ser gay es una pendejada. ${ }^{19}$

Dada a presença de homofóbicos ou pessoas com dificuldades em conviver com as diferenças culturais, os vídeos caseiros sobre as narrativas de si e circunstâncias específicas da vida de pessoas não heteronormativas são lugares retoricamente ricos e incômodos. No entanto, as e os vloggers, ao mesmo tempo em que aprendem a ter consciência corporal e desenvolver sua performance diante da câmera, aprendem, também, a gerir e contestar a quem deixa comentários positivos ou negativos em seus canais (ALEXANDER e LOSH, 2010, p. 41).

Para muitos sujeitos que não se identificam com as premissas da heterossexualidade, em especial aqueles que vivem em pequenas cidades, zonas rurais e nas periferias das metrópoles, a internet tem sido um lugar importante e acolhedor para expressar-se e conhecer pessoas. Até a década de 9o, o isolamento era algo difícil de transpor, era uma situação crítica e muitas vezes perigosa. A internet facilitou encontrar pessoas com as mesmas afinidades e interesses, para dialogar, trocar experiências e informações e, até mesmo, buscar relacionamentos emocionais e/ou sexuais fortuitos.

Felizmente, como apontam alguns estudos (BINNIE, 2004; GROSS, 2007), os jovens têm cada vez menos dificuldades para assumir suas sexualidades não hegemônicas, pois estão encontrando menos motivos para tratar de reprimir ou ocultar suas identidades. Jennifer Egan (2000), inclusive, aponta que os adolescentes homossexuais saem do armário cada vez mais cedo em parte pelo apoio e a interatividade das redes digitais. Além disso, é importante enfatizar que os vídeos também são canais de denúncias de abuso, reivindicações 
políticas e humanitárias, petições públicas, homenagens a pessoas vítimas de violência, organização de eventos e de mobilização, entras outras ações.

Há muitos vídeos que publicitam as experiências cotidianas das identidades sexualmente dissidentes e com uma simples busca em Youtube usando as expressões "sair do armário", "dicas para sair do armário", "conselhos para sair do armário" e outras variantes dos termos, aparecerão centenas de vídeos que revelam essas experiências. Assim, o que antes era íntimo e do mundo privado, passa a ser de domínio público. Esses vídeos funcionam como declarações intencionais de representação e visam negociar as fronteiras entre o "eu" e o "outro". Os sujeitos produtores desses vídeos têm a intenção de afirmar seu lugar no mundo, saem do padrão das retóricas tradicionais para expor formas alternativas de compreensão das práticas de subjetividade das identidades dissidentes, além de oferecer conteúdos criativos e de difusão eficiente.

\section{Comentários finais}

As redes digitais são novos mundos sociais, onde o potencial discursivo e as representações visuais são apresentados por meio da hipervisibilidade e da exposição de detalhes que outrora faziam parte do âmbito privado. Esses ambientes tornam-se, portanto, espaços privilegiados para o exercício das diferenças e da pluralidade, pois oferecem a seus habitantes a possibilidade de explorar múltiplas características de suas identidades mediadas pelas tecnologias. Nesse sentido, é importante não esquecer que "quando olhamos (e produzimos) as manifestações que formam parte da cultura visual, não estamos apenas olhando o mundo, mas sim as pessoas e suas representações e as consequências que têm sobre seus posicionamentos sociais" (HERNÁNDEZ, 2005, p. 29) ${ }^{20}$.

A propagação das redes digitais aconteceu simultaneamente com o desenvolvimento dos dispositivos móveis e acompanharam a tendência mundial de ver, ser visto, perceber e interpretar o mundo através das telas luminosas dos artefatos eletrônicos. Um avanço tão grande em um período relativamente curto sugere que as redes digitais e as ferramentas relacionadas a essas tecnologias são um fenômeno cujas implicações repercutem de forma incisiva nas práticas cotidianas de milhões de pessoas. Também é importante considerar que a diferenciação entre os contextos online e offline está cada vez mais imprecisa e as interações sociais se sobrepõem entre os es- 
paços mediados e analógicos, influenciando-se mutuamente.

As culturas instauradas nas redes sociais acompanharam nossa dependência pelo visual, nossa compulsão em consumir imagens e nosso desejo de sermos também mais produtores de visualidades (HERNÁNDEZ, 2013). Neste sentido, as ciberculturas proporcionam territórios ricos para discutir questões relacionadas à cultura visual e aos estudos culturais e, como não poderia deixar de ser, despertou o interesse de investigadoras e investigadores que perceberam o impacto e a influência dessas ferramentas tecnológicas na vida das pessoas. As redes sociais se transformaram em um âmbito a mais do social (boyd e ELLISON, 2008, p. 210) e têm, claramente, um papel protagonista dentro dos movimentos do dia a dia.

Sabemos que as pessoas estão cada vez mais conectadas e a conectividade é a chave para as experiências desde o digital. As identidades na internet se movimentam de acordo como desejam ser percebidas pelas demais, transmitindo a informação mais adequada no momento mais conveniente. Vão construindo suas presenças nas redes sociais de acordo com as experiências acumuladas e as negociações com os outros sujeitos on-line, em um jogo de estímulos e respostas aos diversos fragmentos narrativos que circulam pelos ambientes.

Para terminar, gostaria de dizer que ainda está ressonando na cabeça a reclamação recorrente nos estudos de Byung-Chul Han (2013) para parar a máquina, fazer silêncio e desacelerar o pensamento. Essa ideia tão romântica de voltar a um passado idealizado onde aparentemente reinava a tranquilidade e o slow time, parece ser, cada vez mais, uma metáfora improvável na contemporaneidade.

\section{NOTAS}

1. Tradução livre de: "es su propio objeto de publicidad. Todo se mide en su valor de exposición” (BYUNG-CHUL, 2013, p. 29).

2. Tradução livre de: "un mercado en el que se exponen, venden y consumen intimidades” (BYUNG-CHUL, 2013, p. 68).

3. Self-disclosure pode ser traduzido literalmente como "autorrevelação". No entanto, no corpo do texto, optei por não traduzir para o português, porque não expressa as peculiaridades do término e não alcança a essência do significado da expressão em inglês.

4. Narrativas, segundo Hernández (2007a, p. 9), são formas de estabelecer como deve ser pensada e vivida a experiência. Neste artigo, as narrativas se referem às muitas maneiras de "contar" as experiências desde o digital e estão formadas por elementos que se combinam e se interconectam: palavras, imagens, sons, vídeos, etc. 
5. Por hipertextualidade se entende as formas segundo as quais pensamos, comunicamos ou registramos pensamentos, expressões e subjetividades nos ambientes digitais, por meio de uma mescla de elementos que podem ser usados de forma conjugada ou separados, tais como: textos, imagens, sons, vídeos, gráficos, ilustrações ou links.

6. Tradução livre de: "La necesidad de confirmar la realidad y dilatar la experiencia mediante fotografías es un consumismo estético al que hoy todos son adictos. Las sociedades industriales transforman a sus ciudadanos en yonquis a las imágenes; es la forma más irresistible de contaminación mental" (SONTAG, 2006, p. 43).

7. Webquest é um método e estratégia que utiliza os recursos da internet para coletar informações para a pesquisa. Foi proposto por Bernie Dodge, em 1995, com o objetivo de estimular a pesquisa e o pensamento crítico no âmbito da educação.

8. Neste artigo, optei por não traduzir ou corrigir os erros gramaticais das narrativas dos sujeitos participantes da investigação, para manter a originalidade de suas falas e das comunicações realizadas desde o digital, que possuem uma estrutura diferenciada se comparada às situações offline.

9. Tradução livre de: - Eu gosto de tirar fotos e colocá-los online para que outras pessoas saibam o que gosto de fazer, sem ter que fazer-me óbvio. - Bem, eu vejo como entretenimento, serve para brincar com lxs amigxs. Embora reconheça que, de certa forma, também estou buscando a aprovação dxs demais, eu acho que é uma maneira de alimentar o ego ou preencher algum tipo de carência, ou a necessidade de reafirmar-me comigo mesmo, para que me vejam como realmente sinto ou sou, de mostrar-me de alguma forma. - Na minha opinião, é muito interessante porque assim podemos trocar experiências, conhecer novos mundos através de viagens que fazem nossos amigos, ver outros objetos, outros físicos, outros rostos, novas culturas, moda ... enfim, há muitas marcas maneiras de conhecer o desconhecido e se aventurar em um mundo de imagens e, de uma forma ou de outra, aprender. Também brinca com os nossos sentidos, gostos e sensações, já que nem sempre estamos de acordo com tudo o que vemos ou o que as pessoas compartilham. - É como um: hein, olha-me, estou aqui! - Olhar pela janela do vizinho janela sempre foi um vício de muitos. A Internet é a nossa janela virtual, mas muito mais ampla e permissão de de entrada. Hoje, quanto mais compartilhamos mais cresce a necessidade de continuar olhando.

10. Ver: <http://www.elpais.com.uy/vida-actual/selfie-generar-problemas-mentales.html>

11. Ver: <http://www.bestcomputerscienceschools.net/selfies/>

12. Pamela Rutledge publica seus estudos sobre os selfies regularmente no blog The Media Psychology: <http://mprcenter.org/blog/page/2/?s=selfie>

13. A autora prefere ser citada com seu nome escrito em letras minúsculas e tem seu nome registrado dessa maneira.

14. Não vou te enganar, é claro que às vezes me invade o medo, e mais do que uma vez eu pensei em deletar minha conta do Youtube, mas sempre mudei de ideia por uma razão simples: eu gosto do que faço, e isso é mais importante que todo o resto. Escrever é minha paixão, os vídeos do Youtube é um suplemento que me faz rir muito, por isso continuo a fazer as duas coisas, até que deixe de gosta de fazê-las.

15. Oi meninos, como estão? O tema de hoje é como sair do armário. Me pediram este vídeo e sinto que é bom compartilhar esse tipo de coisa, porque muitos permanecem no armário, não sabem como sair do armário, contar a seus pais, à família ... então eu vou contar a minha história (...), pois chega a um ponto de sua vida que já não quer fingir quem você não é. Minha história não foi tão difícil quanto outros casos, porque sempre fui muito feminina e, na verdade, a maioria das pessoas já sabiam que ele era gay ... então foi tipo confirmar. 
16. Lésbicas, gays, bissexuais, transexuais, transgêneros, travestis, transformistas, intersexuais e queers.

17. Lhes quero contar como foi minha saída do armário. Minha saída foi dia 31 de dezembro, mas o fiz porque minha mãe pegou algumas mensagens antes do jantar de Ano Novo. Tive que explicar o porquê das mensagens ... Lhe contei sobre minha orientação sexual e para ela foi como uma "explosão", porque primeiro ela pediu que não contasse a ninguém. Mas... a quem eu digo, com quem me desabafo?

18. Depois de um tempo minha mãe me diz que a verdade para ela foi muito forte naquele momento. (...) Hoje, com a minha família, tudo está perfeito. Quero então que considerem pensar um pouco em seus pais ... obviamente, dizer que tem uma orientação sexual diferente é algo muito forte, então deem tempo para passar a dor, pata que eles possam se informar e tudo mais. Mas, se você se você se sentir preparado para dizer-lhes, diga!

19. - Uau! Como você é corajoso, ainda me da medo sair do armário, eu sinto como se meu mundo inteiro vai mudar drasticamente se eu fizer isso, você tem dicas? - Idiota! Eu não entendo porque são gays! - Parabéns, você é muito corajoso. Eu tento dizer a minha mãe que eu sou bissexual e cada vez que toco no assunto toda minha família fala sobre como isso é horrível e nunca me aceitariam. É muito triste que nem todos nos aceitam, e assim só nos resta permanecer em silêncio. - Eu não entendo porque falam tanto de "sociedade", "aceitação" etc etc. Não entendo porque eles fazem vozinha de mulher, porque se vestem de rosa. Por acaso não existe um homossexual que não tenha essa voz e nem se vista assim? - Olá, quero felicitá-lo por ter a coragem de fazê-lo. Sei de muitos "heteros" que lamentam por ter que viver atados a uma esposa toda a sua vida. - Eu também sou bonito e não preciso para me tornar uma marica. Eu muito homem ... e estou feliz de se-lo e amo as mulheres mais do que qualquer coisa na vida. Isso de ser gay é uma "pentelhação".

20. Tradução livre de: "cuando miramos (y producimos) las manifestaciones que forman parte de la cultura visual no estamos sólo mirando al mundo, sino a las personas y sus representaciones y las consecuencias que tienen sobre sus posicionalidades sociales, de género, clase, raza, sexo, etc." (HERNÁNDEZ, 2005, p. 29).

\section{Referências}

ALEXANDER, ; LOSH,. A YouTube of One's Own? In: PULLEN, C.; COOPER , M. LGBT Identity and Online New Media. New York: Routledge, 2010. p. 37-50.

BAUDRILLARD, J. Cultura y simulacro. Tradução de Pedro Rovira. Barcelona: Kairós, 1978.

BELLI, S. Emociones y lenguaje. Universidad Autònoma de Barcelona. Barcelona. 2009.

BINNIE, J. The globalization of sexuality. London: Sage, 2004. 167 p. ISBN: 9780761959366.

boyd, d. Dear Voyeur, meet Flâneur... Sincerely, Social Media. Surveillance \& Society, 8, n. 4, 2011. p. 505-507. Disponível em: <http://www.surveillance-and-society.org>. Acesso em: 10 jun. 2013.

boyd, d.; ELLISON, N. B. Social network sites: Definition, history, and scholarship. Journal of Computer-Mediated Com- 
munication, 13, n. 1, 17 dez. 2008. p. 210-230. Disponível em: $<$ http://www.danah.org/papers/JCMCIntro.pdf>. Acesso em: 25 fev. 2014.

BRUNER, J. La fábrica de historias: Derecho, literatura, vida. Buenos Aires: Fondo de Cultura Económica, 2003.

BYUNG-CHUL, H. La sociedad de la transparencia. Tradução de Raúl Gabas. Barcelona: Herder Editorial, 2013.

CONELLY, M.; CLANDININ, J. Relatos de Experiencia e Investigación Narrativa. In: LARROSA, J. Déjame que te cuente. Ensayos sobre narrativa y educación. Barcelona: Laertes, 1995. p. 11-59.

ECO, U. La estrategia de la ilusión. Tradução de Edgardo Oviedo. Barcelona: DeBolsillo, 2012. ISBN: 9788499895109.

EGAN,. Lonely gay teen seeking same. The New York Times Magazine, 10 dez. 2000. 110-113. Disponível em: <http:// www.nytimes.com/200o/12/10/magazine/lonely-gay-teen-seeking-same.html>. Acesso em: 15 nov. 2014.

GROSS, L. Forword. In: O'RIORDAN, K.; PHILLIPS , D. J. Queer Online: Media, Technology and Sexuality. [S.l.]: Peter Lang Publishing, 2007. p. 7-10.

HERNÁNDEZ, F. ¿De qué hablamos cuando hablamos de cultura visual? Educação e Realidade, 30, n. 2, jul/dez 2005. p. 9-34.

HERNÁNDEZ, F. Espigador@s de la Cultura visual. Otra narrativa para la educación de artes visuales. Barcelona: Octaedro, 2007.

HERNÁNDEZ, F. Transitar y aprender dentro y fuera de la escuela: la relación de los jóvenes con la cultura visual como espacio de posibilidad y autoría. In: EDARTE Investigar con jóvenes: ¿Qué sabemos de los jóvenes como productores de cultura visual? Pamplona: Pamiela - Edarte (UPNA/ NUP), 2013. p. 83-92.

ÍNIIGUEZ, L.; BELLI, S.; HARRÉ, R. Tecnoemociones y discurso: la performance emocional. Revista Electrónica de Motivación y Emoción, España, 13, n. 34, 2010. 1-31. Disponível em: <http://reme.uji.es/articulos/numero34/article6/texto.html>. Acesso em: 30.3.2014. ISSN-e 1138-493X.

KEEN, A. Vertigem digital: por que as redes sociais estão nos dividindo, diminuindo e desorientando? Tradução de Alexandre Martins. Rio de Janeiro: Zahar, 2012.

MEHDIZADEH,. Self-Presentation 2.0: Narcissism and Self-Esteem on Facebook. Cyberpsychology, Behavior, and Social Networking, 13, n. 4, August 2010. p. 357-364. 
MITCHELL, W. J. T. Picture Theory. Chicago: The University of Chicago Press, 1994.

QIAN, H.; SCOTT, C. R. Anonymity and self-disclosure on weblogs. Journal of Computer-Mediated Communication, 12, n. 4, July 2007. p. 1428-1451.

SONTAG, S. Sobre La Fotografia. Tradução de Carlos Gardini e Aurelio Major. México: Sancillana Ediciones Generales, 2006.

Recebido em: 27/02/15

Aceito em: 01/04/15

\section{CARLA LUZIA DE ABREU \\ carlaluzia@gmail.com}

Doutora em "Artes Visuales y Educación" (2014), pela Facultad de Bellas Artes, Universidad de Barcelona (UB), Espanha, em regime de cotutela com a Universidade Federal de Goiás (UFG), Brasil. Mestre em "Educación y Artes Visuales: un enfoque construccionista" (2010, UB). Licenciada em Artes Visuais pela Faculdade de Artes Visuais (2007, FAVUFG). Atualmente é pesquisadora do Grupo de Estudos Cultura Visual e Educação (FAV/UFG) e bolsista PNPD-CAPES, pelo programa de pósgraduação em Arte e Cultura Visual da Universidade Federal de Goiás. 